\title{
Preliminary observations on the plasma composition of liza klunzingeri from the strait of Hormuz (Persian gulf)
}

\author{
Maria Mohammadizadeh ${ }^{1 *}$, Majid Afkhami ${ }^{2}$, Kazem Darvish Bastami ${ }^{3}$, Maryam Ehsanpour $^{2}$ and Reza Esmailpoor ${ }^{2}$
}

\begin{abstract}
Serum biochemistry can be used for monitoring changes in the physiological condition of fish and water quality. The aim of this paper was to determine the concentrations of plasma T3 (Thyroid hormone), thyroxin, TSH (Thyroidstimulating hormone), ALT (Alanine Aminotransferase), AST (Aspartate aminotransferase) and cholesterol of Liza klunzingeri caught on the northern side of the strait of Hormuz (Persian Gulf). Biochemical values were: T3 $0.96 \pm$ $0.58 \mathrm{ng} / \mathrm{ml}$, Thyroxin $76.58 \pm 28.26 \mathrm{ng} / \mathrm{ml}$ TSH $0.03 \pm 0.01 \mathrm{nmol} / \mathrm{L}$, ALT $1.71 \pm 0.68 \mathrm{U} / \mathrm{L}$, AST $49.81 \pm 5.25 \mathrm{U} / \mathrm{L}$ and cholesterol $177.28 \pm 40.75 \mathrm{mg} / \mathrm{di}$. A significant positive correlation $(P<0.01)$ was found between AST and Cholesterol. ALT had a significant and positive correlation with cholesterol and AST $(P<0.01)$. Thyroxin also had a significant and positive correlation with cholesterol $(P<0.01)$ and AST $(P<0.01)$. The results revealed negative correlation between Thyroxin with TSH $(P<0.01)$. This study provides the first data on this blood chemistry of $L$. klunzingeri.
\end{abstract}

Keywords: Liza klunzingeri, T3, TSH, AST, ALT, Hormoz strait

\section{Introduction}

Blood analysis is a useful tool for the diagnosis and health monitoring of animals, as well as to distinguish pathogenic processes from those that might be purely physiological (Christopher et al., 1999). Fish culturists and fish biologists use indices of blood chemistry for evaluating of fish stress responses, nutritional condition, reproductive state, tissue damage due to handling procedures, and health status (Wagner and Congleton, 2004). It is well-known that blood sampling, laboratory techniques, seasonal variations, fish size, genetics patterns, stocking density, food privation, social stress, capture, handling and transport can all influence the biochemical parameters (Rey Vazquez and Guerrero, 2007).

The Persian Gulf is a rich area for fishery resources, and large quantities of fish and shrimps are concentrated in different locations, particularly along the northern side of the Strait of Hormuz. Liza klunzingeri is a shared stock that is native to the Arabian Sea, Indian Ocean, Gulf of Oman and Persian Gulf (Randall, 1995). The

\footnotetext{
* Correspondence: maria.mohamadizadeh450@gmail.com

'Department of environmental management, Islamic Azad University, Bandar abbas branch, P.O.Box:79159-1311, Bandar abbas, Iran

Full list of author information is available at the end of the article
}

abundance of grey mullets in estuarine and coastal areas of tropical, sub-tropical and temperate regions of the world may be related to their food and feeding habits, as they occupy a relatively low position in the food web (Wright, 1988). Despite their worldwide commercial importance, only very limited and disparate information exists on any aspect of the biochemical values in the blood of Liza klunzingeri either locally or regionally (Mohammadizadeh et al., 2012). Normal reference ranges of blood biochemical parameters are considered important for assessing and monitoring the health status of Liza klunzingeri.

\section{Material and methods}

L. (klunzingeri wild samples $(\mathrm{n}=87)$ were captured with a kind of coastal trap net fishing gear (Mushta in local language) from northern side of Strait of Hormuz in 2011. Each fish was quickly caught and while it was physically restrained, a blood sample was collected directly from the heart with syringes coated with sodium heparin. These samples were used for determining the biochemical parameters. For blood plasma assessment, tubes were centrifuged for $5 \mathrm{~min}$ at 3,000 rpm. Then, glass tubes were broken, and the resultant blood plasma 
Table 1 Biological and biochemical parameters (Mean \pm SD) and range recorded for $L$. klunzingeri $(n=87)$

\begin{tabular}{ccccc}
\hline Parameters & $\boldsymbol{N}$ & Mean \pm S.D & Minimum & Maximum \\
\hline Weigh $(\mathrm{g})$ & 87 & $25.35 \pm 5.30$ & 13.27 & 48.77 \\
Total length(cm) & 87 & $129.24 \pm 9.76$ & 105.00 & 151.00 \\
Forked length(cm) & 87 & $119.13 \pm 9.18$ & 95.00 & 140.00 \\
TSH(nmol/L) & 87 & $0.03 \pm 0.01$ & 0.02 & 0.06 \\
Cholesterol(mg/di) & 87 & $177.28 \pm 40.75$ & 115.00 & 241.00 \\
Thyroxin(ng/ml) & 87 & $76.58 \pm 28.26$ & 41.00 & 124.00 \\
T3(ng/ml) & 87 & $0.96 \pm 0.58$ & 0.4 & 1.87 \\
ALT(U/L) & 87 & $1.71 \pm 0.68$ & 1.00 & 3.00 \\
AST $(\mathrm{U} / \mathrm{L})$ & 87 & $49.81 \pm 5.25$ & 41.00 & 59.00 \\
\hline
\end{tabular}

was emptied into sterile micro tubes for further analysis. Serum biochemistry determinations included cholesterol, AST and ALT tests were made using an autoanalyser (Cobas Integra System, France). Hormonal Data tests include T3, Thyroxin, and TSH were made by Vidas Biomerieux system (Electroimmuno Analyzer, France) Strik et al., 2007).

\section{Statistical analysis}

The normality of the data was evaluated by applying the Kolmogorov-Smirnov test. For each normally distributed parameter analyzed the mean and standard deviation were calculated. In addition, Pearson's coefficient was used for linear correlation $(r)$ between variables at $\mathrm{P}<0.05$.

\section{Result}

In order to establish reference ranges, the fish samples were subjected to an external examination and healthy fish were used. The average weight and total length of fish sample were $25.35 \pm 5.30 \mathrm{~g}$ and $129.24 \pm 9.76 \mathrm{~mm}$, respectively (Table 1 ). Water temperature was $28^{\circ} \mathrm{C}, \mathrm{pH}$ was 8.3, dissolved $\mathrm{O}_{2}$ was $6.8 \mathrm{mg} \mathrm{L}^{-1}$, total ammonia nitrogen (TAN) was $<0.5 \mathrm{mg} \mathrm{L}^{-1}$.

The mean, minimum and maximum plasma parameters of L. klunzingeri are given in Table 1 . There were correlations among studied factors in serum, A significant positive correlation $(P<0.01)$ was found between AST and Cholesterol. ALT had a significant and positive relationship with Cholesterol and AST $(P<0.01)$. Thyroxin also had a significant and positive relationship with cholesterol $(P<0.01)$ and AST $(P<0.01)$. The results revealed reveres correlation between Thyroxin with TSH $(P<0.01)$. T3 also had a significant and reveres correlation with TSH $(P<0.01)$ (Table 2).

\section{Discussion}

The study of blood parameters is one of the most valuable diagnostic tools because it has been shown that the physiological values of these parameters are speciesspecific and age-dependent (Anver 2004, Darvish Bastami et al. 2009). One of the difficulties in assessing the state of health of natural fish populations has been the paucity of reliable reference ranges of the normal condition. In pursuant to this goal, many fish physiologists have turned to studies of hematology, probably because this area has proved to be a valuable diagnostic tool in evaluating health. Although fish hematology continues to offer the potential of a valuable tool, progress in establishing normal range values for blood parameters has been slow, and literature in this area is isolated and often incomplete. The biochemical profile can also provide important information on the condition of the organism (Anver, 2004). Accordingly, haematology and serum biochemistry data are of immense importance to help managers monitor the health of both captive and wild population of these species, especially in aquaculture, water quality assessment and etc. The use of a biochemical approach has been advocated to provide an early warning of potentially damaging changes in stressed fish. In toxicological studies of acute exposure, changes in concentrations and enzyme activities often directly reflect cell damage in specific organs (Casillas et al. 1983). Blood parameters included plasma enzyme activities (aspartate aminotransferase (AST), alanine aminotransferase (ALT), alkaline phosphatase (ALP),

Table 2 Correlation between biological and biochemical parameters in L. klunzingeri

\begin{tabular}{|c|c|c|c|c|c|c|c|c|}
\hline Parameters & Total length & Forked length & Weight & Cholesterol & $A S T$ & $A L T t$ & $\mathrm{TSH}$ & Thyroxin \\
\hline Forked length $(\mathrm{cm})$ & $.971^{* *}$ & & & & & & & \\
\hline Weight(g) & $.829^{* *}$ & $.835^{* *}$ & & & & & & \\
\hline Cholesterol(mg/di) & .023 & .027 & .004 & & & & & \\
\hline AST(U/L) & .004 & .024 & -.003 & $.628^{* *}$ & & & & \\
\hline $\mathrm{ALT}(\mathrm{U} / \mathrm{L})$ & -.019 & -.012 & -.002 & $.593^{* *}$ & $.883^{* *}$ & & & \\
\hline $\mathrm{TSH}(\mathrm{nmol} / \mathrm{L})$ & -.026 & -.044 & -.007 & $-.803^{* *}$ & $-.415^{* *}$ & $-.399^{* *}$ & & \\
\hline Thyroxin(ng/ml) & -.005 & .000 & -.018 & $.972^{* *}$ & $.644^{* *}$ & $.582^{* *}$ & $-.791^{* *}$ & \\
\hline T3(ng/ml) & -.005 & -.003 & -.031 & $.981^{* *}$ & $.700^{* *}$ & $.639^{* *}$ & $-.779^{* *}$ & $.984^{* *}$ \\
\hline
\end{tabular}

**. Correlation is significant at the 0.01 level. 
glucose (GLU) and total protein (TP)) of Mullets (Liza saliens) were determined by C. Fernandez et al. (2008) in Esmoriz-Paramos lagoon, Portugal. Authors expressed that the higher glucose and protein contents observed in Liza saliens caught in the lagoon were consistent with a stress response and the measurement of plasma AST activity could be a sensitive indicator of lagoon fish stress.

Thyroid hormones are produced upon activation of the neuroendocrine hypothalamo-pituitary-thyroid (HPT) axis (Blanton and Specker, 2007; Zoeller et al., 2007). Under hypothalamic control, the pituitary secretes thyroidstimulating hormone (TSH) which proceeds to the thyroid gland to activate synthesis of thyroxine (T4) and triiodothyronine (T3). T4 generally represents $>95 \%$ of the thyroid hormone output and it is typically present in higher quantities than T3 in the blood circulation, with the higher $\mathrm{T} 4$ concentrations serving as a pool of prohormone that can be converted into T3 in target tissues (Eales, 2006; Zoeller et al., 2007). Our results also show that T4 and T3 were $76.58 \pm 28.26$ and $0.96 \pm 0.58$, respectively. Thyroid hormones are essential for early development in fishes, including larval-juvenile transitions and induction of metamorphosis (Blanton and Specker, 2007; Klaren et al., 2008). Thyroid hormones are also deposited into the yolk of fish eggs, and used during subsequent embryonic development (Leatherland, 1989). Disruption of thyroid function can have severe consequences as thyroid hormones play an important role in the maintenance of a normal physiological status in vertebrates. In adult fish, thyroid hormones are of primary importance in the regulation of such fundamental physiological processes as growth, nutrient utilization, and reproduction. Fish grow faster and are healthier when thyroid hormone levels are adequate (Power et al., 2001; Yamano, 2005).

AST and ALT belong to the plasma non-functional enzymes which are normally localized within the cells of liver, heart, gills, kidneys, muscle and other organs. It is also considered to be important in assessing the state of the liver and some other organs. Their presence in blood plasma may give information on tissue injury or organ dysfunction. Monitoring of liver enzymes leakage into the blood has proved to be a very useful tool in liver toxic studies (Salah El-Deen \& Rogeps, 1993). In L. klunzingeri average of AST and ALT were: $49.81 \pm 5.25$ and $1.71 \pm$ 0.68 , respectively.

Cholesterol is major degradation products and indicators of carbohydrate, lipid and protein metabolism (Kaplan et al. 1988). In L. klunzingeri minimum and maximum of cholesterol was: 115-241. Blood parameters among fish species may be affected by sampling technique, analyses methods, age, habitat, and diet (Sakamoto et al. 2001). Therefore, values reported here will be useful for the early detection, identification, and monitoring of diseases and sub lethal conditions in this species.

\section{Competing interests}

The authors declare that they have no competing interests.

\section{Authors' contributions}

MM and MA carried out the acquisition, analysis, and interpretation of data, and drafted the manuscript. KA helped in the acquisition and interpretation of data, and performed the statistical analysis. ME conceived of the study, participated in its design and coordination, and revised the manuscript critically for important intellectual content. RE participated in the design of the study and helped draft the manuscript. All authors read and approved the final manuscript.

\section{Authors' information}

MM is a scientific member of Environment Department of Islamic Azad University, Bandar Abbas Branch, MA and ME are Master student of Fisheries Department, KA is scientific member of Iranian National Institute for Oceanography and RE is Pathology lab technician.

\section{Acknowledgement}

The authors wish to acknowledge the Bandar abass branch Islamic Azad University for financial support and cooperation in this project.

\section{Author details}

'Department of environmental management, Islamic Azad University, Bandar abbas branch, P.O.Box:79159-1311, Bandar abbas, Iran. ${ }^{2}$ Islamic Azad University, Bandar Abbas Branch, P.O.Box:79159-1311, Bandar Abbas, Iran. ${ }^{3}$ Iranian National Institute for Oceanography (INIO), P.O. Box 46515-369, Tehran, Iran.

Received: 16 October 2012 Accepted: 15 January 2013

Published: 21 February 2013

\section{References}

Anver CE (2004) Blood chemistry (electrolytes, lipoprotein and enzymes) values of black scorpion fish (Scorpaenaporcus, 1758) in the Dardnelles. Turkey J Biol Sci 4:716-719

Blanton ML, Specker JL (2007) The hypothalamic-pituitary-thyroid (HPT) axis in fish and its role in fish development and reproduction. Crit Rev Toxicol 37:97-115

Fernandes C, Fontaínhas-Fernandes A, Rocha E, Salgado MA (2008) Monitoring pollution in Esmoriz-Paramos lagoon, Portugal: Liver histological and biochemical effects in Liza saliens. Environ Monit Assess 145:1-3, 315-322

Casillas E, Myers M, Ames E (1983) Relationship of serum chemistry values to liver and kidney histophathology in English sole (Parophrys vetulus) after acute exposure to carbon tetrachloride. Aquat Toxicol 3:61-78

Christopher MM, Berry KH, Wallis IR, Nagy KA, Henen BT, Peterson CC (1999) Reference intervals and physiologic alterations in hematologic and biochemical values of free-ranging desert tortoises in the Mojave desert. J Wildl Dis 35(2):212-238

Darvish BK, Haji MA, Mohamadi ZA, Salehi Mir SV, Shakiba MM (2009) Measurement of some hematological characteristics of the wild carp. Comp Clin Pathol 18(3):321-323

Eales JG (2006) Modes of action and physiological effects of thyroid hormones in fish. In: Reinecke M, Zaccone G, Kapoor BG (eds) Fish Endocrinology, vol 2. Science Publishers, Plymouth, UK, pp 767-808

Kaplan A, Ozabo LL, Ophem KE (1988) Clinical Chemistry: Interpretation and Techniques, 3rd edn. Lea \& Febiger, Philadelphia

Klaren P, Wunderink Y, Yufera M, Mancera J, Flik G (2008) The thyroid gland and thyroid hormones in Senegalese sole (Solea senegalensis) during early development and metamorphosis. Gen Comp Endocrinol 155:686-694

Leatherland JF (1989) Thyroid hormone content of eggs and early developmental stages of five oncorhynchus species. Can J Fish Aquat Sci 46:2140-2145

Mohammadizadeh, Afkhami M, Bastami KD, Ehsanpour M, Kazaali A, Soltani F (2012) Determination of some biochemical values in the blood of Liza klunzingeri from the coastal water of the Persian gulf. Afr J Biotechnol 11 (12):2862-2868

Power DM, Llewellyn L, Faustino M, Nowell MA, Bjrnsson BT, Einarsdottir IE, Canario AVM, Sweeney GE (2001) Thyroid hormones in growth and development of fish. Comp Biochem Physiol C Toxicol Pharmacol 130:447-459

Randall JE (1995) Coastal Fishes of Oman. Univ. Hawaii Press, Honolulu, p 439 
Vazquez RG, Guerrero GA (2007) Caracterization of blood cells and hematological parameters in Cichlsoma dimerus. Journal Tissue Cell 39:151-160

SalahEl-Deen M, Rogeps WA (1993) Changes in total protein and transaminase activities of grass carp exposed to diquat. J Aquatic Animal Health 5:280-286

Sakamoto K, Lewbart GA, Smith TM (2001) Blood chemistry values of juvenile red pacu (piaractus brachypomus). Vet Clin Pathol 30:50-52

Strik N, Alleman AR, Harr KE (2007) Circulating inflammatory cells. In: Jacobson E (ed) Infectious Diseases and Pathology of Reptiles. CRC Press, Boca Raton, Florida, U.S.A., pp 165-214

Yamano K (2005) The role of thyroid hormone in fish development with reference to aquaculture. JARQ 39:161-168

Wagner T, Congleton JL (2004) Blood chemistry correlates of nutritional condition, tissue damage, and stress in migrating juvenile Chinook salmon (oncorhynchus tshawytscha). Can J Fish Aquat Sci 61:1066-1107

Wright JM (1988) Seasonal patterns and trophic relationships of fish assemblage of the non-estuarine sulaibikhat Bay. Kuwait Mar Biol 100:13-20

Zoeller RT (2007) Environmental chemicals impacting the thyroid: targets and consequences. Thyroid 17:811-817

doi:10.1186/2193-1801-2-62

Cite this article as: Mohammadizadeh et al:: Preliminary observations on the plasma composition of liza klunzingeri from the strait

of Hormuz (Persian gulf). SpringerPlus 2013 2:62.

\section{Submit your manuscript to a SpringerOpen ${ }^{\circ}$ journal and benefit from:}

- Convenient online submission

- Rigorous peer review

- Immediate publication on acceptance

- Open access: articles freely available online

- High visibility within the field

- Retaining the copyright to your article

Submit your next manuscript at $\gg$ springeropen.com 